LOCAL WISDOM, 12 (1): 1 - 9, 2020
Local Wisdom Scientific Online Journal
ISSN: 2086-3764 $\quad \begin{array}{r}\text { WISDOM } \\ \mathrm{w}\end{array}$

\title{
The Morphology of Hierarchy Limasan House Space in Kertosari Ponorogo
}

Wahyuni Eka Sari ${ }^{1 *}$

1. Magister Architecture, University of Brawijaya, Malang, Indonesia

Corresponding Author: sariekawahyuni@gmail.com

\begin{tabular}{ll}
\hline & Abstract \\
\cline { 2 - 3 } $\begin{array}{l}\text { Keywords: } \\
\text { Morphology, }\end{array}$ & Limasan house is one of the traditional houses in Java. Limasan house \\
House & is a house that functions as a residence that has a unique form. \\
& Limasan house is found in Ponorogo Regency including Kertosari \\
Village. Kertosari Village was once a batik producing center in \\
Ponorogo Regency. The Limasan house in Kertosari Village used to \\
function as a home to produce batik. The Limasan house which is \\
now in Kertosari Village has started to be abandoned and neglected \\
without any maintenance. The hierarchy of space becomes an \\
important unit in the part of the house. Hierarchy is formed because \\
of various factors. The purpose of this study was to find out how the \\
morphology of the space hierarchy of the Limasan House has its \\
unique shape. The method used is descriptive analysis with \\
exposure to the results of field surveys. The results obtained from \\
this study are changes from the hierarchy of space inside the Limasan \\
house that used to be in the living room of the main building, now \\
turning into a living room or middle room as its hierarchy.
\end{tabular}

DOI: https://doi.org/10.26905/lw.v12i1.3615

@ 2017 The Authors. Published by GKAK UNMER Malang

*Corresponding Author: sariekawahyuni@gmail.com

\section{Introduction}

Limasan House functions as a residence used by its owner for daily activities. The main space pattern in the Joglo house is Pendopo, Pringgitan, and Dalem, but in Limasan's house there is no Pringgitan, so Pendopo is integrated with Dalem. The facade that appears are two buildings joined together. Other parts of the house such as Gandok are only found on one side of the house, usually on the right, which is continued towards the kitchen in the back.

Limasan House has a spatial pattern with Pendopo and Dalem separated by walls. Pendopo functioned as a living room and Dalem as a living room or family room. The simpler Limasan house has a simpler pattern, namely Pendopo and Dalem which are fused in one room, so that there is only one building. This pavilion as a living room as well as family room. 
The original building in Limasan's house is usually in the main part of the house, which is Pendopo and Dalem. Many parts of the house such as Gandok and the kitchen have not been functioned or have been replaced with new buildings. The addition of new buildings inside and outside usually functioned as a bedroom. Sentong, which was used as a bedroom, now has not been used or left empty. Changes in function are also possible so that the room is not left empty, such as being used as a bathroom, kitchen, or warehouse.

Morphology explained by (Purwanto and Gultom, 2013) study the development of physical forms in urban areas related to building architecture, open space circulation systems and infrastructure. Morphology is broader than typology because it involves changes in forms that occur in evolution, transformation, metamorphosis or morphogenesis. Morphology is the study of forms and shapes of residential environments. Form means a form that can be observed and is a configuration of several objects, while a shape is a geometric feature or external shape and outline of an object (Carmona et al., 2012) in (Damayanti et al., 2017).

Morphology by (Irawan Setyabudi and Nugroho) is reviewed based on: a. year of development; $b$. the similarity of emergence of elements; c. basic form similarities; $d$. location similarity; e. spatial similarity; f. change factor; g. type of change; h. year of change; and i. the nature of space. According to Alvares in (Mangundap et al., 2018), morphology as an analysis has diachronic and synchronous aspects.

1. Diachronic because there is a change in ideas in history whereas,

2. Synchronous because it has a relationship between parts in a certain period relating to other physical aspects such as structure and physical typology.

Hierarchy becomes a unity that cannot be separated from the building's spatial pattern. There are changes that occur in space in buildings over time, including the space hierarchy. The purpose of this study is to determine the location of a hierarchy in the Limasan House, as well as how the changes and what factors influence it. Descriptive analysis method is used to identify how the morphology of the space hierarchy in Limasan House.

\section{Space Hierarchy}

Hierarchy according (Wastuty, 2008) can be seen the difference from a form in space. The intensity of the interests of a space can be seen from the pen or function of the space. In addition, the meaning and formality of space can be a condition for a hierarchy. The structure of space and the value of space depend on the needs of the perpetrators of activities in space.

The Hierarchy by (Clark and Pause, 1986) on (Wastuty, 2008) can be explained that the ranking of space can determine the importance of a space. This rating can be assessed from large to small, short high, more or less or by measurements from the center to the edge, a little to a lot, often used not often used, to measurements in solid voids. 
The Morphology of Hierarchy Limasan House Space in Kertosari Ponorogo

Wahyuni Eka Sari

Limasan Houses in Kertosari Village were taken as many as 20 houses which are still inhabited and can be entered for assessment. Limasan's house in Kertosari Urban Village is mostly still awake. But not a few houses have been destroyed or damaged.

\begin{tabular}{|c|c|c|}
\hline $\begin{array}{l}\text { House } \\
\text { Case }\end{array}$ & Hierarchy and Transition & Characteristics \\
\hline 1 & 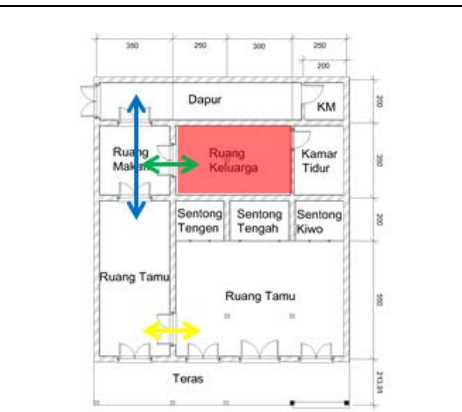 & $\begin{array}{l}\text { - Space hierarchy is in the family } \\
\text { room } \\
\text { - Transition of space is connected } \\
\text { by a door } \\
\text { - Changes in the hierarchy from } \\
\text { the living room to the family } \\
\text { room }\end{array}$ \\
\hline 2 & 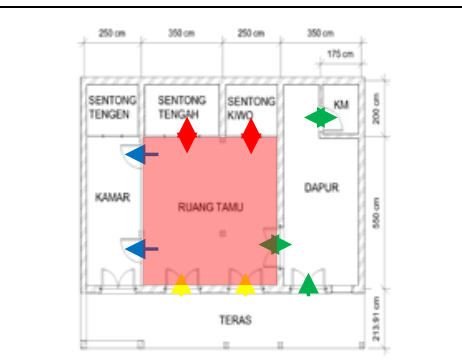 & $\begin{array}{l}\text { - The space hierarchy is in the } \\
\text { living room } \\
\text { - Transition of space is connected } \\
\text { by a door } \\
\text { - Fixed space hierarchy }\end{array}$ \\
\hline
\end{tabular}

3

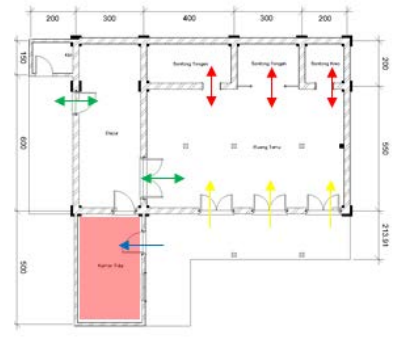

- Space hierarchy is in the bedroom

- Transition of space is connected by a door

- Changes in the hierarchy from the roar of the guest to the bedroom
4

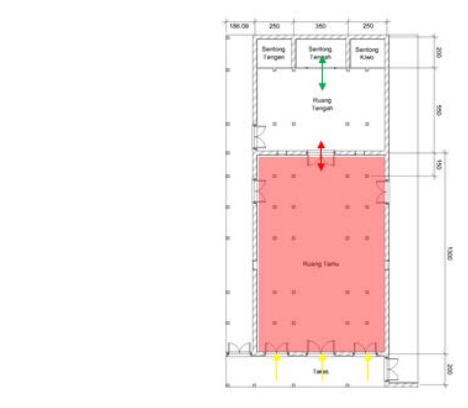

- The space hierarchy is in the living room

- Transition of space is connected by a door

- Fixed space hierarchy
5

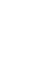




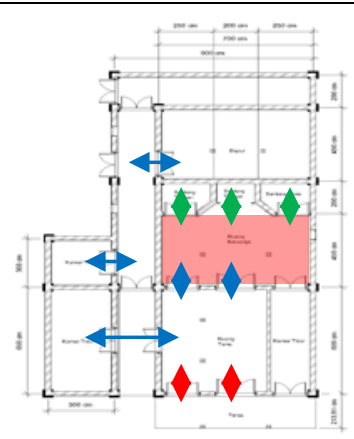

by a door

- Changes in the hierarchy from the living room to the family room

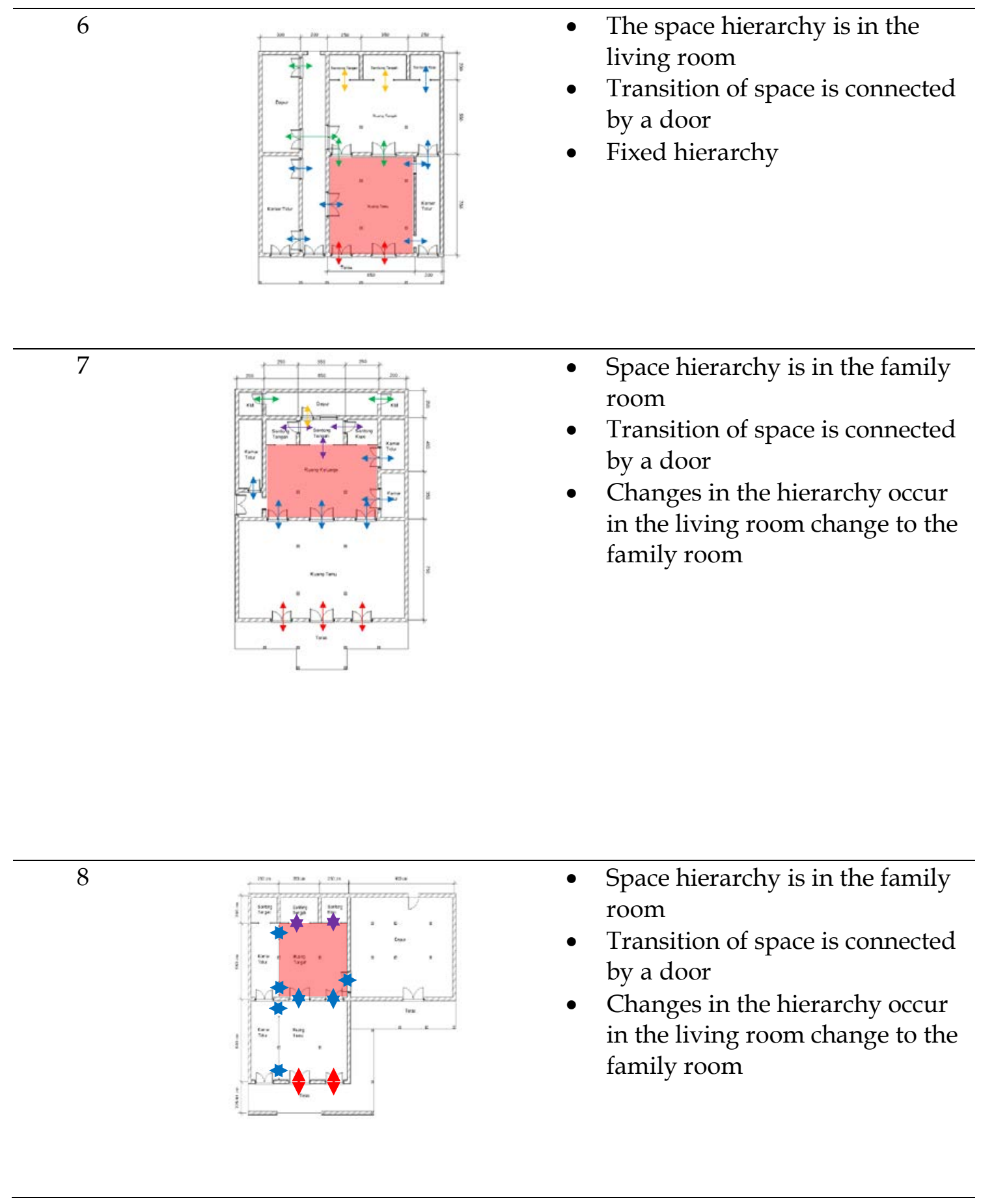


The Morphology of Hierarchy Limasan House Space in Kertosari Ponorogo

Wahyuni Eka Sari

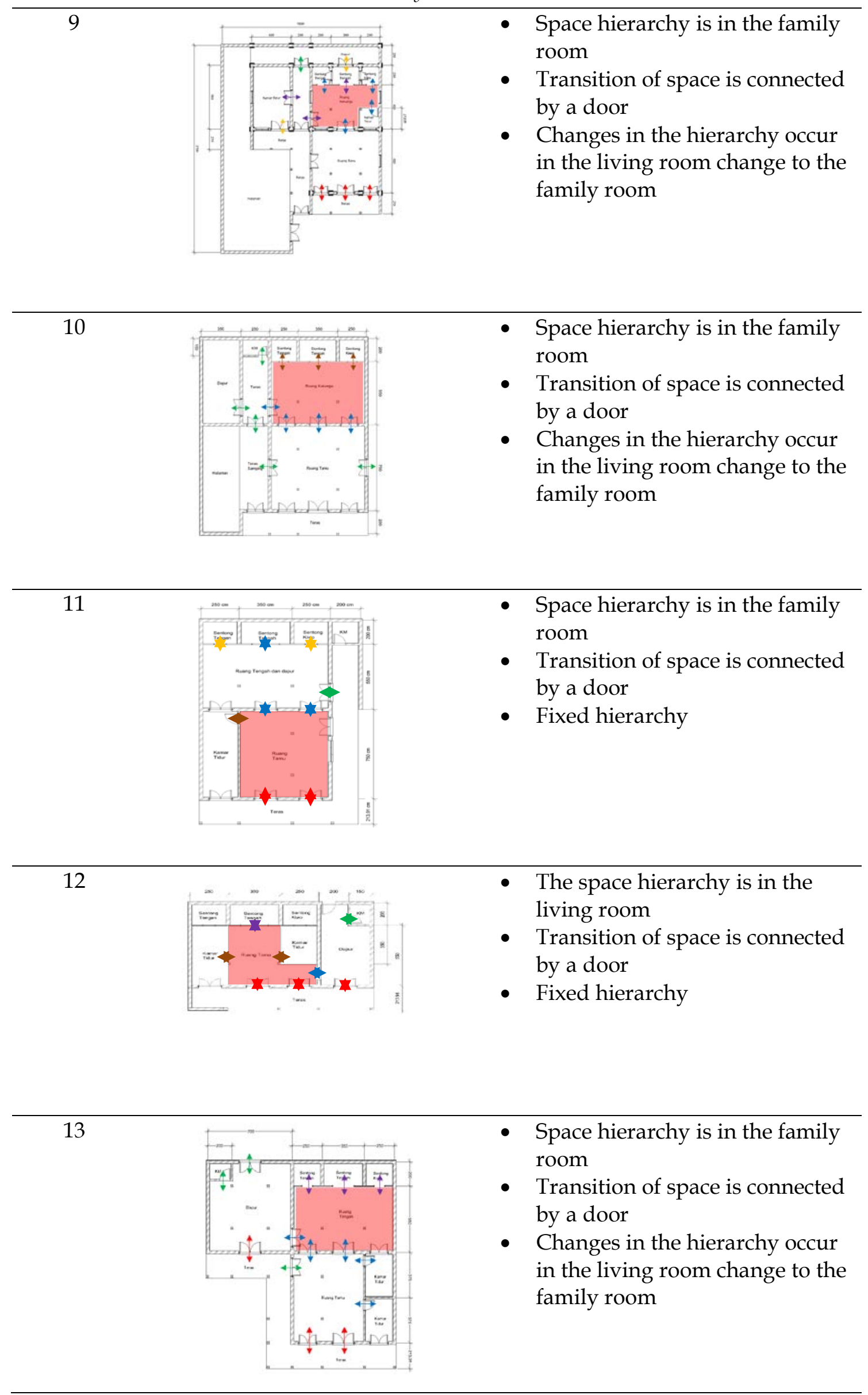


14

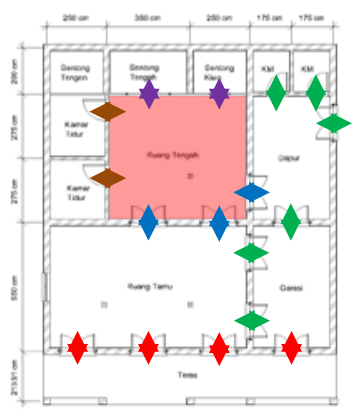

- Space hierarchy is in the family room

- Transition of space is connected by a door

- Changes in the hierarchy occur in the living room change to the family room
15

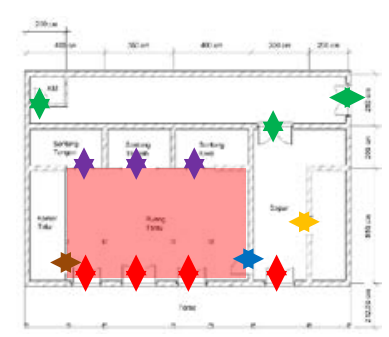

- The space hierarchy is in the living room

- Transition of space is connected by a door

- Fixed hierarchy
16

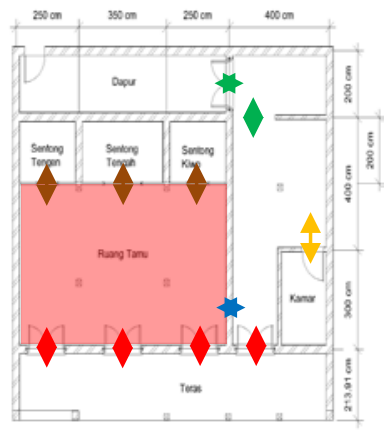

- The space hierarchy is in the living room

- Transition of space is connected by a door

- Fixed hierarchy
17

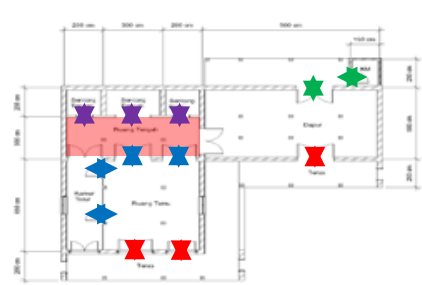

- Space hierarchy is in the family room

- Transition of space is connected by a door

- Changes in the hierarchy occur in the living room change to the family room

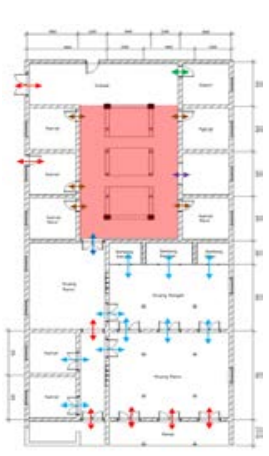

- The space hierarchy is in the back building

- Transition of space is connected by a door

- Changes in the hierarchy occur in the living room change to the back room 


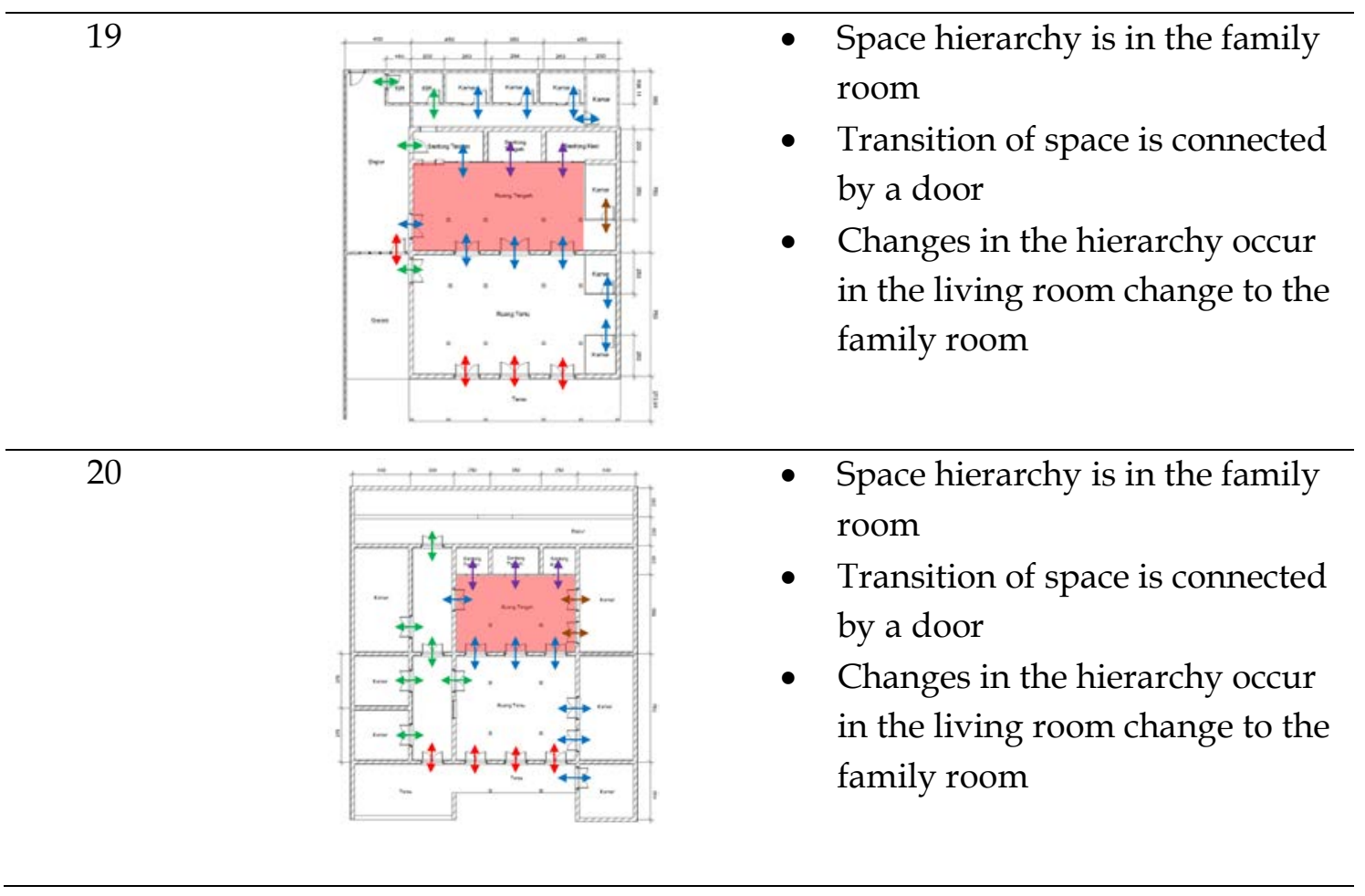

Space hierarchy is in the living room and family room. The living room is the main room in the building, while the family room is a room that has a high intensity as a space that is often used or functioned. The living room also functions as a family room, gathering place, and receiving guests will become a hierarchy in a house. The living room that becomes one with the family room will be seen in the hierarchy because almost all owner activities are centered on the space. Unlike if, the living room and family room are separate, then the hierarchy will be in the family room. The living room is only a place to receive guests, while family interaction is focus on the family room.

Transition of space to each other connected by a door. The door is a link between one room with another room. Space transition becomes a link between one room and another. Transition can also determine the difference in hierarchy in a house. Transition can also be a marker in the house, and also a barrier between spaces with a high hierarchy and spaces with a low hierarchy.

The addition of a separate building from the main building and the main function as a residence, if connected with a transition in the form of a door still remains one with the main building and there is a different access so that the building function is unmixed. The main function remains as a residence, although other functions of the building change as an economic function. The addition of space next to and behind the main building aims to keep interactions and connections in the entire space maintained.

The highest hierarchy is in the family room with additional space. Rumah Limasan has a room with a main building in the front room or living room. In ancient times the front room or living room was the center of all activities. Sentong as a left and right 
bedroom does not require additional space at the side or back. The hierarchy of space used to be in the living room. But over time, the activities and activities of homeowners will increase. Actors in home activities will also increase. The increase in offspring will be a factor for changing or increasing space in the home. So this will cause changes in function to change the hierarchy in the space in the house. Family activities become the main at Limasan house, so this activity is the main factor of space changes in buildings.

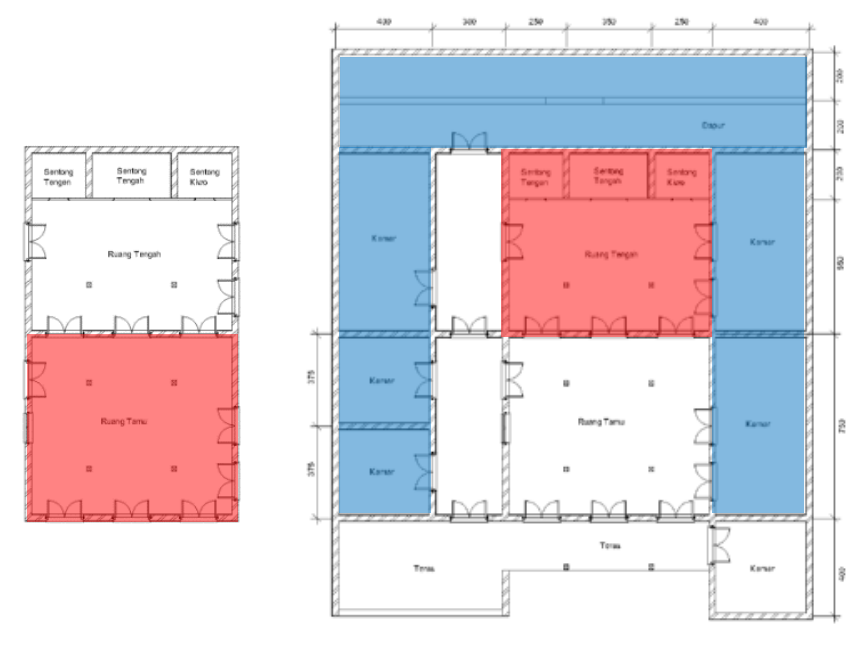

Figure 1: Changes in the space hierarchy in the Limasan House

\section{Conclusion}

Limasan House as a residence becomes the main thing. Seen from the main room which is maintaining as a place of family activity. Changes over time in each corner, as well as the variety of activities, which do not change the essence of the Limasan, house as a Javanese community residence. Various new activities such as selling in the house still do not eliminate the meaning of the family as the main, as seen from the placement of a new space that is separate from the main building and has different access to the house. Increasing space, added activity, and changes that occur, but the Limasan house is still a residential unit that is still maintained until now.

Space hierarchy is in the room that has the highest intensity of activities carried out in the room by all family members. In general, the family room becomes a hierarchy in the house. The family room becomes an important space that is often accessed by the owner. This family room becomes the center of activity for the owner. Many owners use the family room as a place for activities such as chatting, watching television, receiving guests, and other activities. The intensity of activities in each house is different. Some houses that do not have a separate family room and living room will make the living room a family room, so that its function will be mixed. The initial function of the building as a residence has the highest hierarchy in the living room. as time goes by, the addition of buildings and increased function of the building, the hierarchy changes in the family room. This shows that the Limasan house makes family activities first. Adding space and increasing activities that are separate from the main building and different access so that it will not interfere with the activities in the main building. 
The Morphology of Hierarchy Limasan House Space in Kertosari Ponorogo

Wahyuni Eka Sari

The change factor can be influenced by the increasing need for space, activities in the home that are increasingly developing over time, and also the development of the era that allows renewal in terms of building materials.

\section{Reference}

CARMONA, M., HEATH, T., OC, T. \& TIESDELL, S. 2012. Public places-Urban spaces, Routledge.

DAMAYANTI, F., NUGROHO, A. M. \& SANTOSA, H. 2017. TIPOLOGI RUMAH JAWA DI KAWASAN PERDESAAN SUMBER POLAMAN LAWANG. Reka Buana: Jurnal Ilmiah Teknik Sipil dan Teknik Kimia, 2, 56-73.

MANGUNDAP, P., WAANI, J. O. \& TUNGKA, A. 2018. TIPO-MORFOLOGI LAIGAN (RUMAH) MASYARAKAT SALUAN LOINANG BALOA DODA DI KABUPATEN BANGGAI. Fraktal: Jurnal Arsitektur, Kota dan Sains, 2.

PRIMAYUDHA, N. 2015. Tinjauan Pembentukan Kawasan Heritage Budaya Kampung Glam di Singapura dengan Pendekatan Analisis Morfologi dan Tipologi Bangunan. JURNAL ITENAS REKARUPA, 3.

PURWANTO, E. \& GULTOM, J. 2013. KAJIAN TIPO-MORFOLOGI PERMUKIMAN TEPI SUNGAI. Teknik Sipil Universitas Antakusuma, 11, 77-91.

CLARK, R. H. \& PAUSE, M. 1986. Preseden dalam arsitektur, Intermedia.

WASTUTY, P. W. 2008. Hubungan antara Hierarki Ruang Dengan Bentuk dan Ukuran Gapura pada Komplek Mesjid Besar Mataram Kotagede Yogyakarta. Infoteknik, 9, 6181. 